\title{
PENGARUH PERBEDAAN UKURAN KARET BAN BEKAS TERHADAP SIFAT MEKANIK
}

\author{
Multilawati Nasution ${ }^{1}$, Akhmad Aminnullah'2, Bambang Suhendro ${ }^{3}$ \\ 1,2,3 Departemen Teknik Sipil dan Lingkungan, FT, Universitas Gadjah Mada \\ Email: multilawati.nst@gmail.com
}

\begin{abstract}
ABSTRAK
Ban bekas sulit diurai karena salah satu bahan penyusunnya adalah karet sintetis. Ban bekas digunakan untuk kerajinan tangan, namun besar peluang penggunaan ban bekas sebagai material konstruksi. Kajian ini bertujuan untuk membedakan ukuran karet ban bekas berdasarkan lolos saringan no.\#4 (4.8 mm) dan lolos saringan no.\#8 $(2.3 \mathrm{~mm})$. Objek kajian ini adalah kuat tekan dan modulus elastisitas dengan benda uji slinder $(\varnothing 15 \mathrm{~cm} \times 30 \mathrm{~cm})$, kuat lentur dengan benda uji balok $(10 \mathrm{~cm} \times 10 \mathrm{~cm} \times 50 \mathrm{~cm})$, serta kuat tarik dengan benda uji dogbone. Salah satu penyusun mortar adalah karet ban bekas pengganti sebagian dari volume pasir. Kadar karet yang di ambil dari kajian ini adalah $0 \%, 20 \%, 40 \%$ dan $60 \%$. Kajian ini tidak didapatkan perbedaan yang signifikansi yang besar antara penggunaan karet ban bekas lolos saringan no.\#4 (4.8 mm) dan lolos saringan no.\#8 (2.3mm).
\end{abstract}

Kata kunci: ban bekas, kuat tarik, kuat tekan, kuat lentur, modulus elastisitas

\section{ABSTRACT}

Used tires are difficult to decompose because one of the constituent materials is synthetic rubber. Used tires are used for handicrafts, but there is a big chance of using used tires as construction materials. This study aims to differentiate the size of used rubber tires based on sieve No. $4(4.8 \mathrm{~mm})$ and sieve \# $8(2.3 \mathrm{~mm})$. The object of this research is compressive strength and modulus of elasticity with slinder test specimens $(15 \mathrm{~cm} \times 30 \mathrm{~cm})$, flexural strength with beam test specimens $(10 \mathrm{~cm} \times 10 \mathrm{~cm} \times 50 \mathrm{~cm})$, and tensile strength with dogbone specimens. One of the compilers of the mortar is a used tire rubber which partially replaces the volume of sand. The rubber content taken from this study is $0 \%, 20 \%, 40 \%$ and $60 \%$. There was no significant difference between this study between the use of used rubber tires that passed filter No. \#4 $(4.8 \mathrm{~mm})$ and passed filter \# $8(2.3 \mathrm{~mm})$.

Keywords: used tires, tensile strength, compressive strength, flexural strength, modulus of elasticity

\section{PENDAHULUAN}

Permasalahan yang sering terjadi didunia yaitu kurangnya perhatian terhadap pengelolaan ban bekas di Indonesia. Pengelolaan karet ban bekas di Indonesia masih sedikit dibandingkan dengan limbah ban karet, pengelolaan dan pemanfaatan karet ban bekas pada umumnya dijadikan kerajinan seperti sandal, tempat sampah, fender dan kerajinan kursi. Untuk itu perlu adanya daur ulang ban karet limbah pada rekayasa sipil karena di anggap sebagai solusi ekologis dan ekonomis karena keuntungan yang ditawarkan. Salah satu penggunaan daur ulang ban karet bekas pada rekayasa sipil adalah penambahan pada campuran mortar. Mortar merupakan bahan campuran antara pasir,air dan semen. Salah satu fungsi mortar adalah sebagai matrik pengikat pasangan batu bata untuk dinding pengisi. Penggunaan mortar untuk konstruksi yang bersifat struktural misalnya mortar pasangan batu belah, struktur pondasi dan tanggul penahan. Sedangkan yang bersifat nonstruktural misalnya mortar pasangan batu bata untuk dinding pengisi Mortar serat karet ban bekas merupakan solusi ban bekas yang ramah lingkungan karena membuang ban bekas dengan cara mendaur ulang serta menggantikan 
beberapa agregat alami sehingga agregat alami dapat disimpan. Perilaku mekanik yang biasa di tinjau pada mortar antara lain kuat tekan, kuat tarik, serta terhadap serap air (Kardiyono, 2012).

Menurut (Skariah 2016: 1331) Mortar memiliki ketahanan yang tinggi terhadap penetrasi ion klorida. (Yazdi 2015: 1656). Kajian ini akan mendiskripsikan bagaimana beton karet polos adalah karakteristik penyerap energi yang sangat baik, beton karet polos dapat meningkatkan daktalitas, mengurangi berat, mencegah kegagalan rapuh. (Yu 2016: 2). Kajian ini bertujuan untuk lebih memahami sifat-sifat bahan berbasis semen yang dibuat dengan karet dengan berbagai ukuran. Ukuran karet yang di gunakan adalah rubber $A$ (2-4 $\mathrm{mm})$, rubber $\mathrm{B}$ (1-3 $\mathrm{mm})$, dan rubber $\mathrm{C}(0-2$ $\mathrm{mm})$. Ukuran karet mempengaruhi pengeringan susut terutama melalui pengurangan efek pada kemampuan untuk menahan deformasi CRM.

Dengan adanya kajian mengenai mortar serat karet ban bekas, diharapakan dapat mengurangi permasalahan limbah padat, karena karet ban bekas digunakan sebagai agregat pada mortar. Mortar serat karet ban bekas merupakan solusi ban bekas yang ramah lingkungan karena membuang ban bekas dengan cara didaur ulang serta menggantikan beberapa agregat alami sehingga agregat alami dapat disimpan (Yazdi 2015: 1656). Perilaku mekanik yang biasa di tinjau pada mortar antara lain kuat tekan, kuat tarik, serta terhadap serap air (Kardiyono, 2012).

Kajian ini difokuskan pada hal-hal sebagai berikut antara lain:

1. Jenis bahan yang di gunakan adalah serat karet ban bekas mengganti sebagian pasir.

2. Melakukan peninjauan terhadap sifat mekanis yaitu berupa pengujian mutu pasir, pengujian mutu serutan karet, pengujian kuat tekan, pengujian kuat lentur, pengujian kuat tarik, dan redaman.

3. Peraturan-peraturan yang digunaka sebagai acuan pengujian mortar :

a. SNI-03-1970-1990, penyerapan agregat halus.

b. SNI-03-1971-1990, kadar air agregat halus

c. ASTM C128-78, berat jenis pasir.

d. ASTM C128-93, resapan air.

e. ASTM C29/C29M-91, berat volume pasir.

f. ASTM C136-95, analisa saringan

4. Persentase kadar serat karet $0 \%$, $20 \%, 40 \%$, dan $60 \%$ terhadap pasir.

\section{METODE}

Kajian ini di lakukan pada laboratorium Bahan dan Laboratorium Struktur Jurusan Teknik Sipil dan Lingkungan, Fakultas Tenik Universitas Gadjah Mada Yogyakarta.

Adapun bahan yang digunakan akan di jelasakan sebagai berikut:

1. Karet diambil dari PT Lantabur Ban, Jakarta Timur. Diambil dari PT Lantabur dikarenakan pada PT ini banyak memproduksi ban bekas yang digiling menjadi serbuk. Pada kajian ini hanya menggunakan karet ban bekas tanpa kawat yang terdapat pada ban bekas, lalu karet ini dipisahkan dengan menggunakan saringan no \#4(4.8mm) dan saringan no \#8(2.3mm).

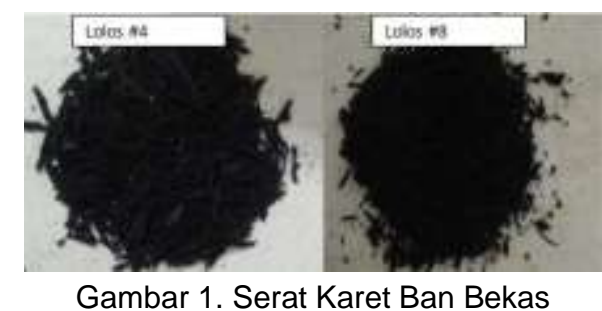

Gambar 1. Serat Karet Ban Bekas 
2. Pasir yang digunakan berasal dari Kulon Progo, setelah pasir datang ke Laboratorium Bahan Bangunan Universitas Gadjah Mada dilakukan penyaringan dengan saringan \#4 (4,8 $\mathrm{mm}$ ) dan dilakukan SSD (Saturdated Surface Dry ).

3. Semen yang digunakan adalah semen tipe I mengunnakan merk Gresik $40 \mathrm{Kg}$.

4. Keresone digunakan untuk pengujian berat jenis karet menggantikan air, di lakukan pergantian air ke minyak tanah di karenakan masih terdapat banyak gelembung ketika melakukan pengujian berat jenis.

Alat yang digunakan pada kajian ini adalah saringan, timbangan, kerucut konic, batang penumbuk, jangka sorong, piknometer, oven pengering, cetok, meja sebar, cetakan benda uji, mesin uji tekan, flexural strength, mesin uji

\section{Proporsi Campuran Mortar}

Perencanaan ini berdasarkan pada berat satuan dan berat jenis. Kadar karet ban bekas yang digunakan pada kajian ini adalah $20 \%$, 40\%, 60\% pada masingmasing diameter karet ban bekas lolos no. \#4 (4.8 mm) dan lolos no.\#8 (2.3 mm).

Pada pengujian campuran juga dilakukan pengujian meja sebar. Dengan syarat meja sebar 70\%-110\% menurut ASTM C230. Pada kajian ini mortar campuran serat karet ban bekas mendapatkan meja sebar antara $90 \%-110 \%$. Pengujian Flow mortar serat karet ban bekas dapat dilihat pada Gambar 2.

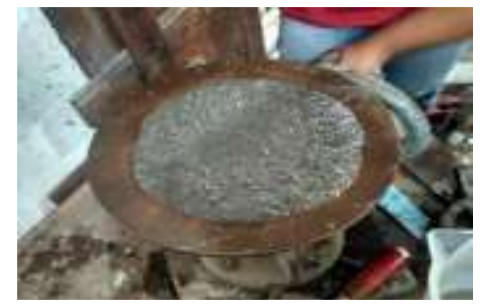

Gambar 2. Pengujian flow mortar
Benda uji berbentuk slinder untuk pengujian kuat tekan dan modulus elastisitas $(\varnothing 15 \mathrm{~cm} \times 30 \mathrm{~cm})$, dogbone untuk pengujian kuat tarik dan balok untuk pengujian lentur $(50 \mathrm{~cm} \times 10 \mathrm{~cm} \times 10 \mathrm{~cm})$. Pengujian ini memiliki benda uji sebanyak 126 buah. Untuk pengujian redaman menggunakan balok.

Pengujian dilakukan pada umur 7 hari dan 28 hari, adapun pengujian yang dilakukan beberapa pengujian sifat mekanik yaitu pengujian kuat tekan, pengujian modulus elastisitas, pengujian kuat tarik serta pengujian kuat lentur. Berikut standar yang digunakan saat pengujian yaitu dibuat pada Tabel 1.

Tabel 1. Standart Pengujian

\begin{tabular}{ccc}
\hline No & Pengujian & $\begin{array}{c}\text { Standar yang } \\
\text { digunakan }\end{array}$ \\
\hline 1 & Kuat Tekan & SNI-03-4431-2011 \\
\hline 2 & Modulus Elastisitas & ASTM 469 \pm 94 \\
\hline 3 & Kuat Tarik & ASTM C 307 - 99 \\
\hline 4 & Kuat Lentur & SNI-4154-2014 \\
\hline
\end{tabular}

dengan,

$\mathrm{P} \quad$ : Beban $(\mathrm{N})$

A : Luas Penampang $\left(\mathrm{mm}^{2}\right)$

$f^{\prime} c$ : Tegangan pada regangan awal

$\left(\mathrm{N} / \mathrm{mm}^{2}\right)$

$$
\begin{aligned}
& E=\frac{\left(S_{2}-S_{1}\right)}{\left(\varepsilon_{2}-\varepsilon_{1}\right)} \quad \ldots \ldots 1 \\
& f^{\prime} c=\frac{\mathrm{P}}{\mathrm{A}}
\end{aligned}
$$

dengan,

E : Modulus elastisitas $\left(\mathrm{N} / \mathrm{mm}^{2}\right)$

$\mathrm{S}_{2} \quad$ : Tegangan pada $40 \%$ beban runtuh

$S_{1} \quad$ : Tegangan pada regangan awal $\left(\varepsilon_{1}\right)$

$\varepsilon_{2}=$ Regangan pada saat tegangan

sebesar $\mathrm{S}_{2}$

$\varepsilon_{1}=$ Regangan awal sebesar 0,00005

$$
s \equiv \frac{P}{b d} \quad \ldots \ldots \quad 3
$$

dengan,

$\mathrm{S} \quad=$ Kuat Tarik $\left(\mathrm{N} / \mathrm{mm}^{2}\right)$

$\mathrm{P} \quad=$ beban maksimum total $(\mathrm{N})$ 
Pengaruh Perbedaan... (Multilawati/ hal 38-48)

b = Lebar benda uji $(\mathrm{mm})$

$\mathrm{d} \quad=$ Tebal benda uji $(\mathrm{mm})$

$f^{\prime \prime} m r=\frac{P L}{B d^{2}} \quad \ldots \ldots \quad 4$

dengan,

$\mathrm{f}^{\prime} \mathrm{mr}=$ Kuat tarik lentur mortar $\left(\mathrm{N} / \mathrm{mm}^{2}\right)$

$\mathrm{P}=$ beban maksimum total $(\mathrm{N})$

$\mathrm{L} \quad=$ Jarak 2 tumpuan $(\mathrm{mm})$

B = Lebar benda uji (mm)

$\mathrm{d} \quad=$ Tebal benda uji $(\mathrm{mm})$

\section{HASIL DAN PEMBAHASAN}

Sebelum melakukan pengujian sifat mekanis yang ada pada mortar serat karet ban bekas, terlebih dahulu melakukan pengujian sifat fisik material yang digunakan. Beberapa pengujian sifat fisik material adalah sebagai berikut.

Pengujian sifat fisik material dari agregat halus (pasir) harus disesuaikan dengan

syarat- syarat yang ada pada SNI. Daı, ${ }^{4} \mathrm{ji}$ material pasir diperoleh beberapa karekteristik pasir dapat dilihat pada di Tabel 2.

Tabel 2. Hasil Pengujian Pasir

\begin{tabular}{clc}
\hline No & \multicolumn{1}{c}{ Pengujian } & Hasil \\
\hline 1 & Berat Jenis Pasir (SSD) & 2.73 \\
\hline 2 & Berat Jenis Pasir Kering & \\
\hline 3 & Kven & 2.68 \\
\hline 4 & Kadar Air & $1.86 \%$ \\
\hline & & $1.08 \%$ \\
\hline & Berat Satuan & $\begin{array}{c}1565.99 \\
\mathrm{~kg} / \mathrm{m} 3\end{array}$ \\
\hline
\end{tabular}

Kajian ini juga dilakukan pengujian gradasi pasir, dimana pengujian ini termasuk pasir yang di kategorikan pada agregat halus no 2 dengan sifat agak kasar Gambar 3. Modulus Halus Butir yang didapatkan sebesar

2.466 .

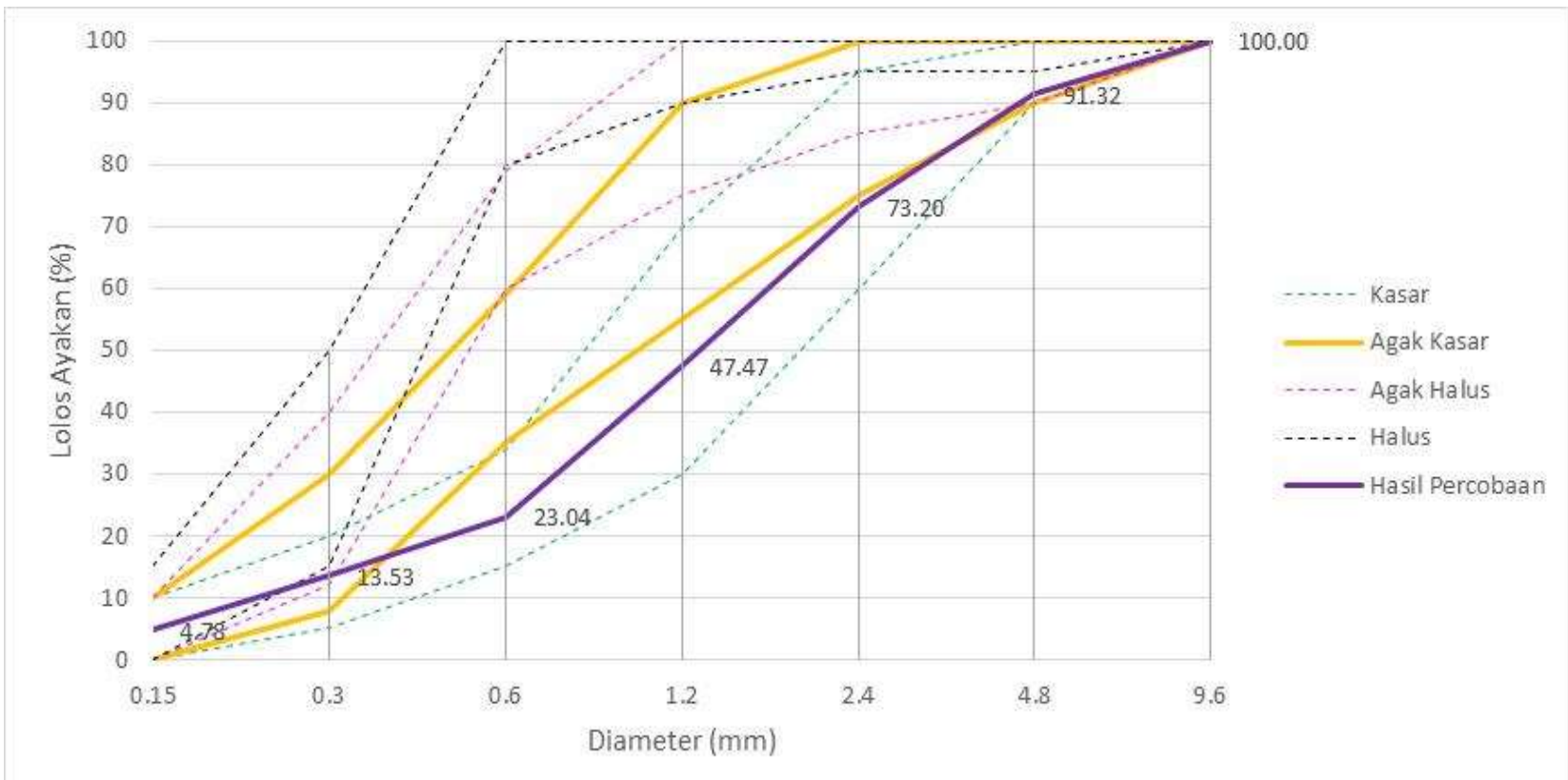

Gambar 3. Pengujian Gradasi Pasir 
Pengujian berat jenis serat karet ban bekas dilakukan dengan ukuran lolos no. \#4 dan lolos no.\#8 menggunakan minyak tanah, pengujian ini dilakukan karena sifat dari material yang ringan dan tidak menyatu dengan air. Pengujian serat karet ban bekas hampir sama dengan pengujian pasir Adapun sifat material pasir dapat dilihat pada Tabel 3.

Tabel 3. Hasil Pengujian Karet

\begin{tabular}{ccc}
\hline No & Pengujian & Hasil \\
\hline 1 & Berat Jenis Karet & 1.14 \\
\hline 2 & Berat Pasir Kering Oven & 1.05 \\
\hline 4 & Berat Satuan lolos \#4 & $421.30 \mathrm{~kg} / \mathrm{m3}$ \\
\hline 5 & Berat Satuan lolos \#8 & $461.05 \mathrm{~kg} / \mathrm{m3}$ \\
\hline
\end{tabular}

Pada campuran karet ban bekas menurut penelitian (Restu, 2019) di Balai Besar Kulit, Karet dan Plastik Yogyakarta. Kajian ini melakukan pengujian tentang massa jenis, kuat tarik serta kekerasan. Hasil kajian ini dapat dilihat pada Tabel 4.

Tabel 4. Pengujian Karet Ban Bekas (Faizah, 2019)

\begin{tabular}{cccccc}
\hline \multirow{2}{*}{ No } & Pengujian & \multicolumn{4}{c}{ Benda Uji } \\
\cline { 3 - 5 } & & A & B & C & D \\
\hline 1 & Massa Jenis $\left(\mathrm{gr} / \mathrm{cm}^{3}\right)$ & 1,112 & 1,09 & 1,12 & 1,136 \\
\hline 2 & Kuat Tarik $(\mathrm{MPa})$ & 10,64 & $\mathbf{1 4 , 3 5 8}$ & 11,896 & 11,792 \\
\hline 3 & Kekerasan (Shore A) & 57,9 & $\mathbf{6 8 , 7 4}$ & 66,98 & 67,6 \\
\hline 4 & Perpanjangan Putus $(\%)$ & $\mathbf{2 9 6}$ & 271 & 238 & 244 \\
\hline 5 & Modulus Elastisitas E (MPa) & 1,8522 & 2,0945 & $\mathbf{2 , 6 1 3 1}$ & 2,488 \\
\hline 6 & Modulus Kekakuan G (MPa) & 0,925 & 1,232 & $\mathbf{1 , 7 6 9}$ & 1,357 \\
\hline
\end{tabular}

Hasil kajian yang dilakukan oleh (Restu, 2019), bahwa kuat tarik tertinggi didapatkan pada sampel B sebesar 14,358 $\mathrm{MPa}$, kekerasan tertingi pada sampel $\mathrm{B}$ sebesar 68,74 Shore A dan massa jenis pada sampel D sebesar 1,136 $\left(\mathrm{gr} / \mathrm{cm}^{3}\right)$.

Pengujian kuat tekan dilakukan pada mesin UTM dan CTM. Pengujian dilakukan berbeda karena kuat tekan yang rendah didapatkan pada campuran karet ban bekas rendah. Adapun hasil penguijian dapat dilihat pada Gambar 4.
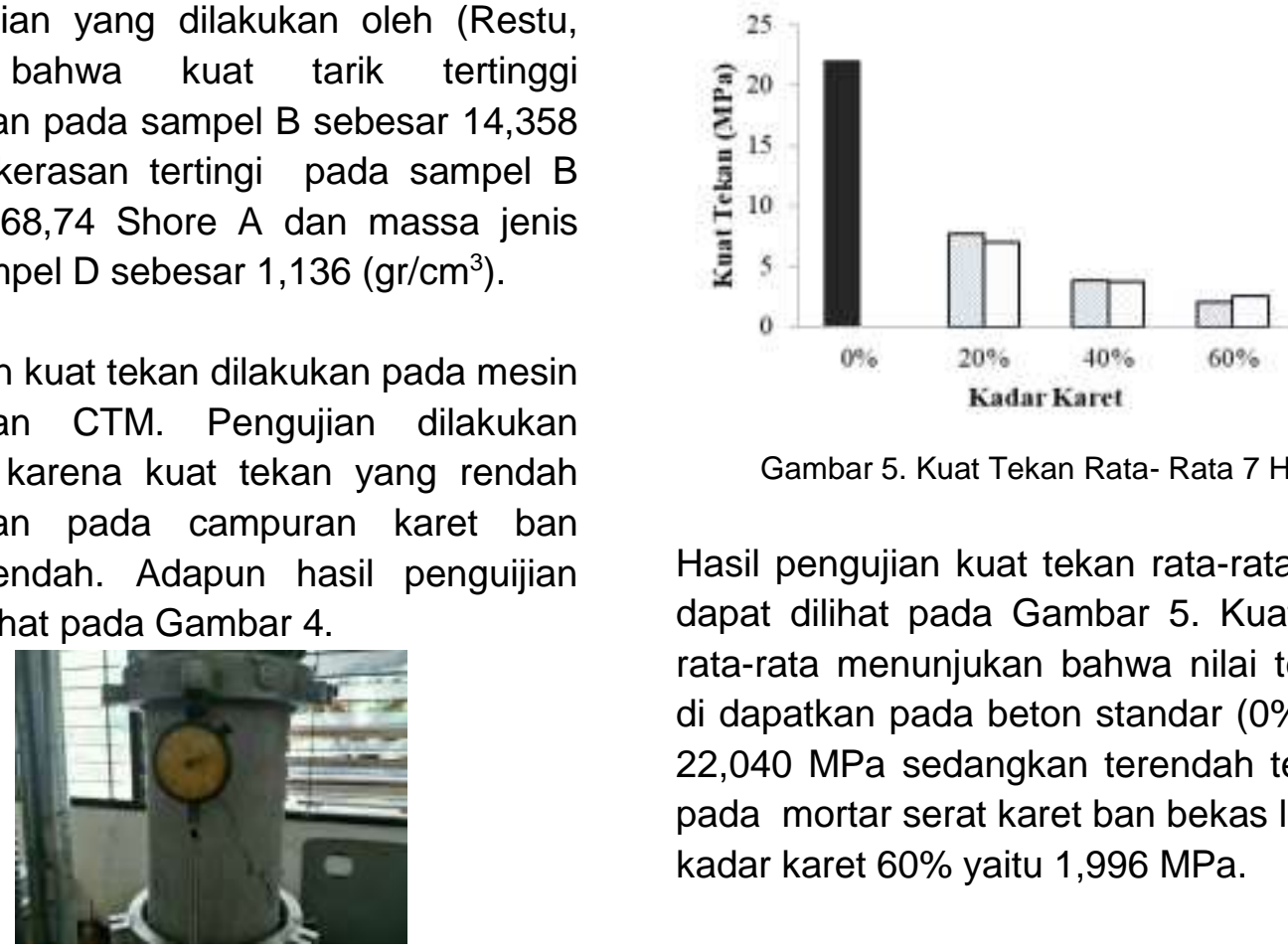

Gambar 5. Kuat Tekan Rata- Rata 7 Hari

Hasil pengujian kuat tekan rata-rata 7 hari dapat dilihat pada Gambar 5. Kuat tekan rata-rata menunjukan bahwa nilai tertinggi di dapatkan pada beton standar $(0 \%)$ yaitu 22,040 MPa sedangkan terendah terdapat pada mortar serat karet ban bekas lolos \#4 kadar karet $60 \%$ yaitu $1,996 \mathrm{MPa}$. 


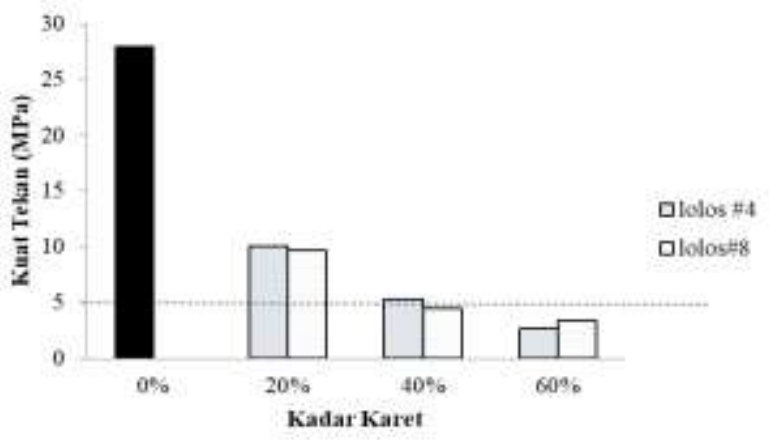

Gambar 6. Kuat Tekan Rata-Rata 28 Hari

Hasil pengujian kuat tekan rata-rata 28 hari yang ditunjukkan pada Gambar 6, bahwa nilai tertinggi didapatkan pada beton standar (0\%) yaitu 27,949 MPa sedangkan terendah terdapat pada mortar serat karet ban bekas $60 \%$ lolos \#4 yaitu 2,677 MPa. Menurut standar BS 5628-1-1992 nilai kuat tekan karekteristik untuk semua dinding pasangan bata yaitu $2,5 \mathrm{~N} / \mathrm{mm}^{2}$, sehingga data kuat tekan rata-rata hasil dari kajian yang di dapatkan sesuai standar, karena nilai yang terkecil masih terletak di atas standar BS 5628-1-1992.

SNI 15-2094-2000 mensyaratan kuat tekan minimal $50 \mathrm{~kg} / \mathrm{cm} 2$ atau $5 \mathrm{MPa}$ untuk bata merah pejal. Sebaiknya antara kuat tekan batu bata dan kuat tekan mortar nilainya seimbang, dikarenakan salah satu fungsi mortar yaitu pelekat antar pasangan bata. Hasil kajian ini yang terdapat ketidaksesuain dengan standar adalah lolos \#8 kadar 40\%, lolos \#4 kadar $60 \%$ dan lolos \#8 kadar 60\%. Beberapa Penelitan mengenai bata merah yang terdapat di Yogyakarta diantaranya, Setiyaningsih (2009) mengatakan batu bata merah dari Pleret memiliki kuat tekan rata-rata sebesar 1,656 $\mathrm{MPa}$, Prayuda (2016) melakukan pengujian batu bata merah dari Pleret, emiliki kuat tekan ratarata sebesar 2,630 $\mathrm{MPa}$. Serta Raharjo dalam Prayuda (2016) melakukan penelitian bahwa batu bata merah dari kabupaten Bantul memiliki kuat tekan ratarata sebesar 2,617 MPa.
Pengujian modulus elastisitas di uji berdasarkan standar ASTM C 469. Dalam handbook Laboratorium Uji Bahan Jurusan Teknik Sipil Politeknik Negeri Bandung menjelaskan mengenai 3 kondisi pembebanan yang terus diberikan terhadap benda uji, diantaranya sebagai berikut.

1. Kondisi Plastis

2. Kondisi Elastisitas

3. Kondisi Patah

Pengujian yang pada mortar karet adalah kondisi elastis. Kondisi elatis merupakan kondisi mortar diberi sampai beban maksimal, setelah mencapai beban maksimal, mortar karet meregang sampai ke posisi semula.

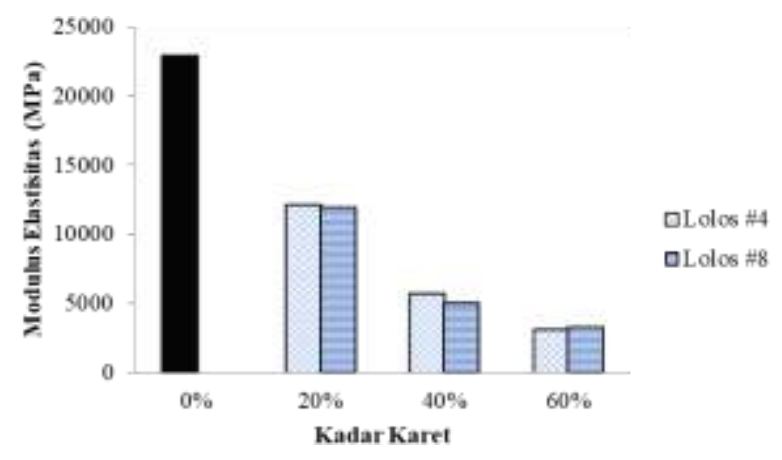

Gambar 7. Modulus Elastisitas Rata-Rata 28 Hari

Berdasarkan Gambar 7. nilai modulus elastisitas rata-rata 28 hari terbesar di dapatkan pada mortar normal $(0 \%)$ yaitu 22903,09715 MPa dan nilai terkecil didapatakan pada lolos \#4 (4.8 mm) yaitu 3203,126071 MPa. menurut Nyoman (2016) diperoleh modulus elastisitas pasangan bata Gianyar sebagai berikut:

a. $240 \mathrm{~N} / \mathrm{mm}^{2}$ untuk mortar perbandingan semen dan pasir 1:4

b. $\quad 191 \mathrm{~N} / \mathrm{mm}^{2}$ untuk mortar perbandingan semen dan pasir 1:5

c. $\quad 171 \mathrm{~N} / \mathrm{mm}^{2}$ untuk mortar perbandingan semen dan pasir 1:6

d. $156 \mathrm{~N} / \mathrm{mm}^{2}$ untuk mortar perbandingan semen dan pasir 1:7 
e. $154 \mathrm{~N} / \mathrm{mm}^{2}$ untuk mortar perbandingan semen dan pasir 1:8

Nilai modulus elastisitas pada kajian serat karet ban bekas dibandingkan dengan hasil diatas, maka kajian serat karet ban bekas jauh lebih tinggi dibandingkan dengan hasil penelitian yang dilakukan Nyoman (2016).

Pengujian kuat tarik mortar menggunakan alat mesin kuat tarik dengan benda uji yang digunakan adalah dogbone. Pengujain ini mengunakan C ASTM C 307-99. Pengujian kuat tarik dapat dilihat pada Gambar 8.

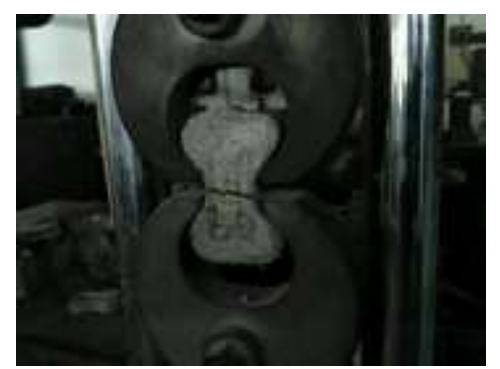

Gambar 8. Pengujian Kuat Tarik

Pengujian kuat tarik pada Gambar 8 adalah pengujian kadar karet dengan kadar karet $60 \%$ lolos \#8. Pada pengujian mortar dengan kandungan karet dapat menahan retak resistensi yang terjadi pada mortar.

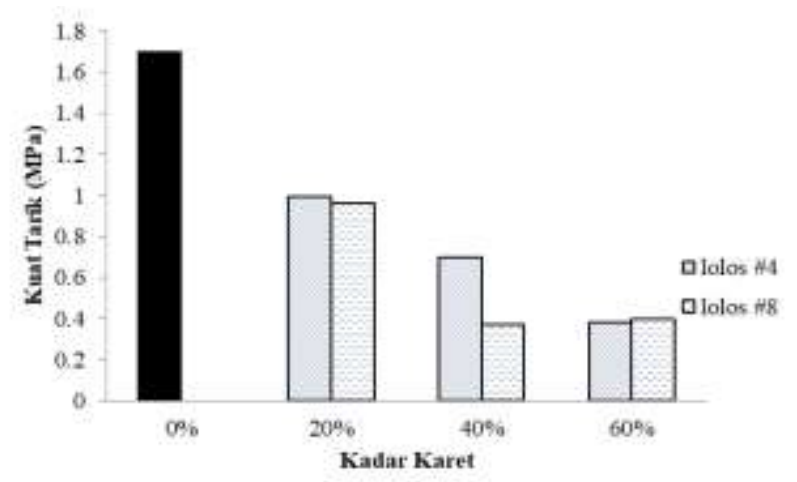

Gambar 9. Hasil Pengujian Kuat Tarik Rata-Rata 7 Hari

Hasil pengujian kuat tarik rata-rata 7 hari dapat dilihat pada Gambar 5.8, bahwa nilai tertinggi di dapatkan pada beton normal
(0\%) yaitu 1,702 MPa sedangkan terendah terdapat pada mortar serat karet ban bekas lolos \#8 dengan kadar karet ban bekas $60 \%$ yaitu $0,360 \mathrm{MPa}$.

Hasil pengujian kuat tarik rata-rata umur 28 hari, akan di sajikan pada diagram, yang dapat dilhat pada Gambar 10.

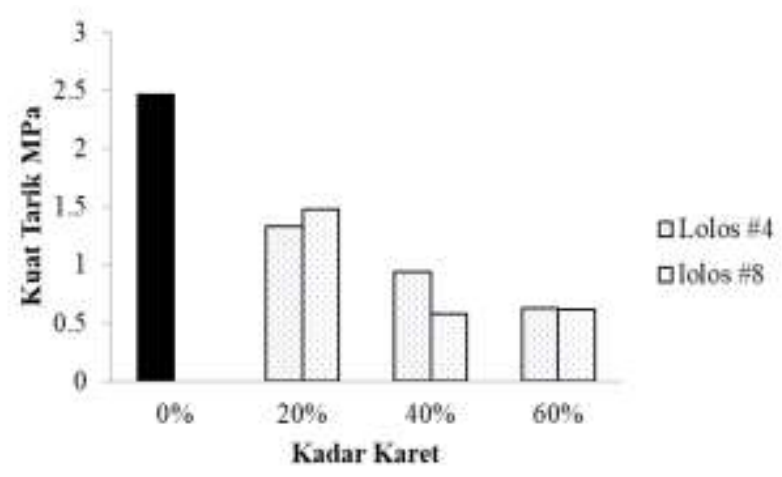

Gambar 10. Kuat Tarik Rata-Rata 28 Hari

Hasil pengujian kuat tarik rata-rata 28 hari dapat dilihat pada Gambar 10, bahwa nilai tertinggi didapatkan pada beton normal $(0 \%)$ yaitu 2,466 MPa sedangkan terendah terdapat pada mortar serat karet ban bekas lolos \#8 dengan kadar karet ban bekas $60 \%$ yaitu $0,360 \mathrm{MPa}$.

Pengujian Kuat lentur menggunakan balok $10 \mathrm{~cm} \times 50 \mathrm{~cm} \times 50 \mathrm{~cm}$, pengujian ini didasarkan dengan SNI 4154:2014. Pengujian kuat lentur dapat dilihat pada Gambar 11.

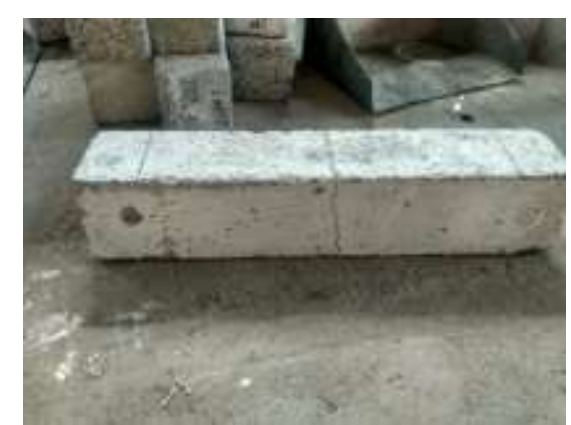

Gambar 11. Hasil Pengujian Kuat Lentur Kadar 60\%

INERSIA, Vol. XVI No. 1, Mei 2020 


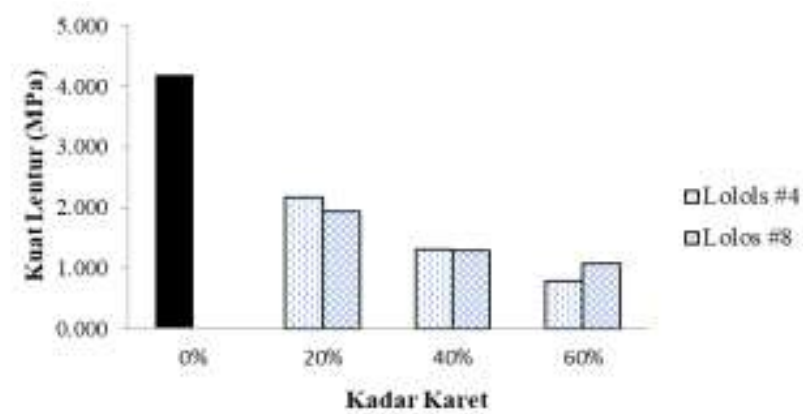

Gambar 12. Hasil Pengujian Kuat Lentur Rata-Rata 7 Hari

Kuat lentur terbesar terdapat pada morta normal sebesar 4,178 $\mathrm{MPa}$ dan yang paling terkecil terdapat pada mortar $60 \%$ lolos \#4 sebesar 0,744 MPa. Hasil pengujian kuat lentur rata-rata 28 Hari disajikan pada Gambar 13.

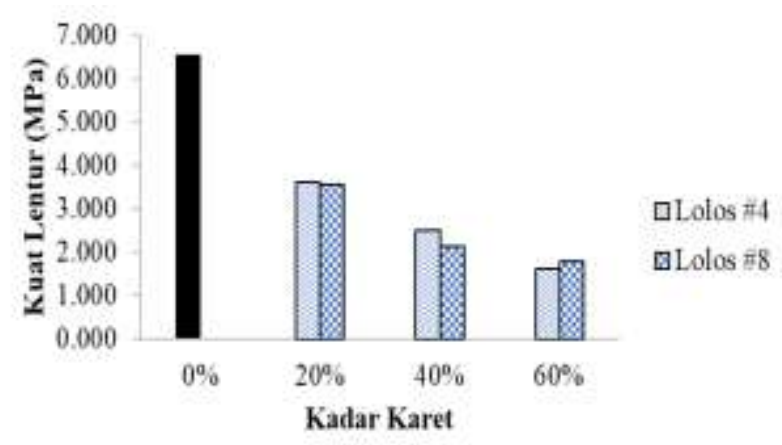

Gambar 13. Kuat Lentur Rata-Rata 28 Hari

Hasil pengujian yang didapatkan bahwa tertinggi di dapatkan pada beton standar (0\%) 6,538 MPa dan yang paling terkecil didapatkan sebesar $1,161 \mathrm{MPa}$ pada mortar lolos \#8 kadar karet $60 \%$. Ini terihat bahwa semakin rendah nilai kuat lentur yang didapatkan dengan adanya penambahan karet yang semakin tinggi.

Analisa pendekatan dengan metoda regresi ini dilakukan untuk melihat hubungan antara pengujian sifat mekanik dengan kadarnya, sehingga pendekatan pada umur pengujian umur 7 hari dan pengujian umur 28 hari dapat dilihat pada grafik dibawah ini.

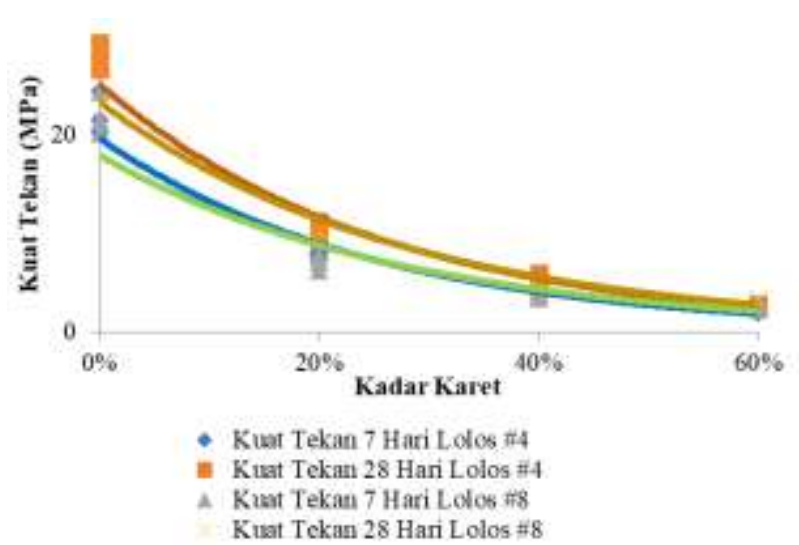

Gambar 14. Metode regresi hubungan antara kuat tekan dengan kadar karet

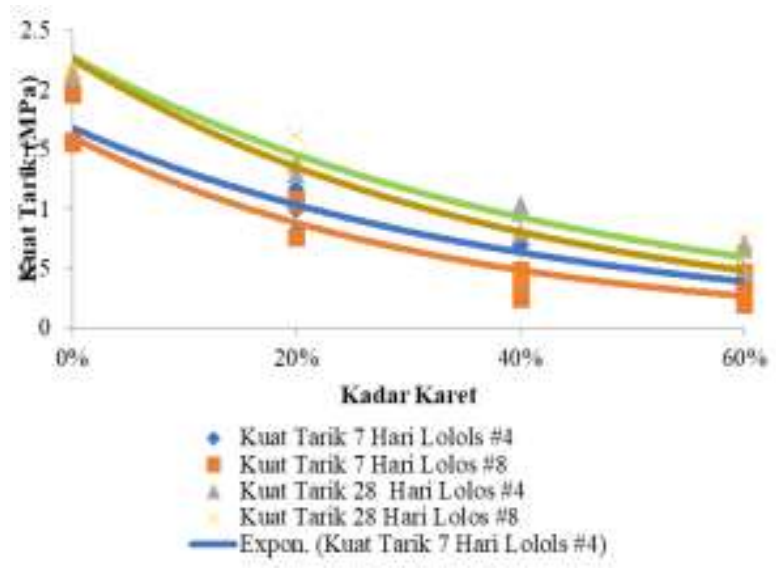

Gambar 15. Metode regresi hubungan anatar kuat tarik dengan kadar karet

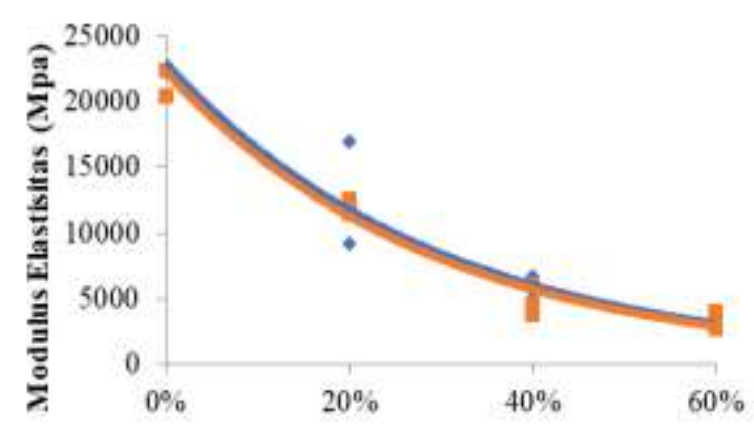

$$
\text { - Lolos \#4 Kadar Serat Karet Ban Bekas }
$$

Gambar 16. Metode regresi hubungan anatar modulus elastisitas dengan kadar karet 


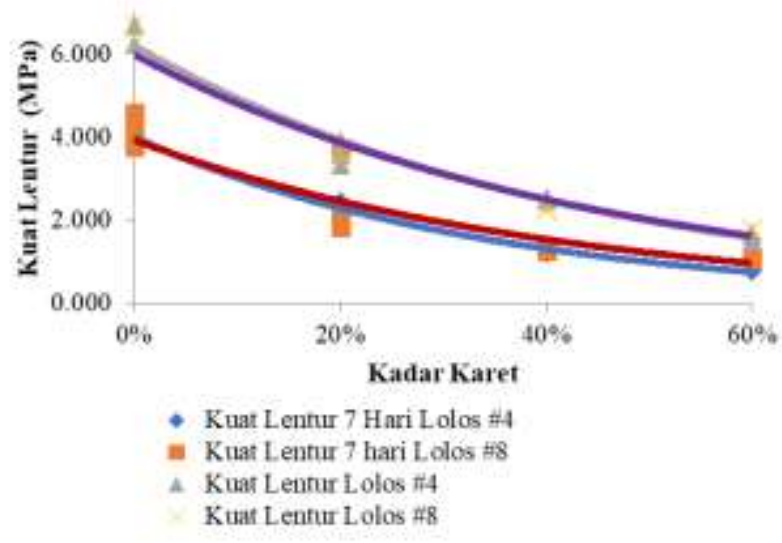

Gambar 17. Metode regresi hubungan anatar kuat lentur dengan kadar karet

Hasil metode regresi ke empat sifat mekanik dapat dilihat pada Gambar 14 sampai dengan Gambar 17, bahwa tidak terdapat perubahan yang besar antara lolos saringan \#4 (4.8 $\mathrm{mm})$ dan lolos saringan \#8 (2.3 mm). Sifat mekanik pengujian umur 7 hari dan pengujian 28 hari tidak ada kenaikan yang begitu besar, ini dikarenakan kurangnya ikatan antara karet ban bekas dengan material lainnya, karet ban bekas memiliki tekstur dengan permukaan yang licin serta berat jenisnya yang lebih ringan. Menurut (Yazdi 2015: 1657), pengurangan kekuatan akibat adanya peningkatan kandungan karet, pengurangan kekuatan menjadi dua alasan yaitu:

1) Retakan yang dimulai di sekitar partikel-partikel karet karena lunaknya partikel karet dapat mempercepat kegagalan matriks karet-semen.

2) Kedua, karena kurangnya kekuatan ikatan dan adhesi antara partikel karet dan pasta semen, partikel karet lunak dapat berperilaku sebagai rongga dalam matriks beton.
(Xue 2017: 3) kekuatan beton menurun ketika persentase karet remah meningkat, penurunan disebabkan oleh:

1) Karena sifat dari karet polymer tanpa ada akitivasi hidrasi dan semen bersifat

2) anorganik sehingga ikatan antara keduanya lemah

3) Ketika partikel karet konten ditingkatkan sampai batas tertentu, itu akan menyebabkan diskontinuitas struktural internal.

4) Jumlah pencampuran melebihi maksimum pori, kekuatan tekan akan melemah.

(Yu 2016: 7). Pengaruh karet pada pengurangan kekuatan CRM adalah dari dua aspek yaitu:

1) kekakuan karet kurang dari pasir untuk modulus elastisitas pasta semen menjadi hampir 3000 kali dari karet.

2) Lebih banyak porositas dihasilkan dalam mortar karena kandungan karet meningkat, terutama ketika karet berukuran kecil digunakan.

Kajian ini juga menggunakan SPPS untuk melakukan pengujian sigfikansi yaitu pengujian signifikansi T. Penggunaan pengujian signifikansi $T$ dikarenakan hanya melakukan signifikansi dengan dua variabel. Berikut hasil dari uji signifikansi dapat dilihat pada Tabel 5. Berikut salah satu penjabaran dari hasil signifikansi yaitu: 
Pengaruh Perbedaan... (Multilawati/ hal 38-48)

Tabel 5. Hasil Pengujian Signifikansi

\begin{tabular}{clccc}
\hline No & \multicolumn{1}{c}{ Pengujian } & Signifikansi & Nilai Rata-Rata & Standar Deviasi \\
\hline 1 & Kuat Tekan Lolos \#4 & 0,973 & 11,492 & 10,327 \\
\hline 2 & Kuat Tekan Lolos \#8 & 0,973 & 11,349 & 10,329 \\
\hline 3 & Kuat Tarik Lolos \#4 & 0,865 & 1,340 & 0,771 \\
\hline 4 & Kuat Tarik Lolos \#8 & 0,865 & 1,283 & 0,850 \\
\hline 5 & Kuat Lentur Lolos \#4 & 0,965 & 3,565 & 1,946 \\
\hline 6 & Kuat Lentur Lolos \#8 & 0,965 & 3,530 & 1,941 \\
\hline 7 & Modulus Elastitas Lolos \#4 & 0,909 & 11115,434 & 8238,679 \\
\hline 8 & Modulus Elastitas Lolos \#8 & 0,909 & 10728,349 & 8201,840 \\
\hline
\end{tabular}

Ho : rata-rata kuat tekan 28 hari lolos no. \#4 (4.8 mm) tidak berbeda dengan rata rata kuat tekan 28 hari lolos \#8 (2.3 mm).

$\mathrm{H} 1$ : rata-rata kuat tekan 28 hari lolos no. \#4 (4.8mm) berbeda dengan rata-rata kuat tekan 28 hari lolos no. \#8 (2.3 mm).

Jika sig.(2-tailed) $<\alpha$ berarti berbeda signifikan

Jika sig.(2-tailed) $>\alpha$ berarti berbeda tidak signifikan

\section{SIMPULAN}

Berdasarkan hasil di atas didapatkan simpulan sebagai berikut: 1) tidak adanya perubahan yang signifikan antara penggunaan lolos no.4 $(4.8 \mathrm{~mm})$ dan lolos

\section{DAFTAR RUJUKAN}

A, M. Yazdi. A Review on Application of Waste Tire in Concrete. World Academy of Science, Engineering and Technology International Journal of Civil and Environmental Engineering. (2015). Vol:9, No:12.

Aldo, A., \& Pratama, G. N. I. (2019). EVALUASI KETAHANAN GEMPA RUMAH SEDERHANA DI KELURAHAN RUM, KOTA TIDORE KEPULAUAN. INformasi dan Ekspose hasil Riset Teknik Slpil dan Arsitektur, 15(2), 1-9.
Digunakan tingkat signifikansi $(\alpha)=0,05$ sig. (2-tailed) $>\alpha(0,973>0,05)$ berarti ratarata kuat tekan 28 hari lolos no.\#4 (4.8 $\mathrm{mm}$ ) sebesar 11,4918 berbeda tidak signifikan dengan rata-rata kuat tekan 28 hari lolos no.\#8 (2.3mm) sebesar 11,3486. Hasil ini menunjukkan perbedaan ukuran lolos no.\#4 (4.8mm) dan ukuran lolos no.\#8 $(2.3 \mathrm{~mm})$ tidak berpengaruh terhadap kuat tekan (MPa).

no.8 (2.3mm); 2) ikatan antara karet yang kurang, sehingga kenaikan antara umur 7 hari hingga umur 28 hari dengan adanya penambahan karet tidak terlalu besar; 3) sifat mekanik yang didapatkan nilai tertinggi terdapat pada beton normal $(0 \%)$.

ASTM C 307 - 99. Standart Test Method for Tensil Stength of- Chemicl- Resistant Mortar, Grouts, and Monolitichic Sufacings.

ASTM C230. Standart Specification for Flow Table FOR Use in Test of Hydraulic Cement.

ASTM C469. Standart Test Method for Static Modulus of Elasticity and poison's Ratio of concrete in Compression. 
Badan Standarisasi Nasional, 2000. Bata Merah Pejal untuk Pasangan Dinding Bata.SNI-15-2094-2002, Jakarta.

Badan Standarisasi Nasional, 2011. Metode Pengujian kuat Tekan Beton SNI-03-4431-2011. Jakarta.

BS 5628-1-1992. Structural Use of Unreinforced Masonry.

Faizah, R. The Properties of Waste Rubber Tires in Increasing the Damping of Masonry Wall Structure, 2019 (belum dipublikasikan).

Handbook Laboratorium Uji Bahan Jurusan Teknik Sipil Politeknik Negeri Bandung.

Kardiyono, Tjokrodimuljo. 2012. Teknologi Beton, Yogyakarta: KMTS FT UGM.

Nyoman, Ni Rita Rahayu. Study Karekteristik Bata Merah Lokal Bali Sebagai Dinding. Jurnal Spektran (2016).10-18.

Pratama, G. N. I. P., \& Sumarjo, H. (2018). Aksesibilitas Tata Letak Elevator Penumpang Gedung Kantor Pusat Layanan Terpadu (KPLT) Fakultas Teknik UNY. INformasi dan Ekspose hasil Riset Teknik Slpil dan Arsitektur, 14(1), 26-35.

Prayuda, Hakas. 2016. Prediksi Lateral In Plane Melalui Perubahan Frekuensi
Alami dan Redaman Struktur Dinding Pasangan Bata 1/2 Batu dengan Spesi 1 PC : 4 KP : 10 PSMelalui Analisis Getaran Mikro. Jurusan Teknik Sipil dan Lingkungan, Fakultas Teknik, Universitas Gadjah Mada, Yogyakarta.

Setiyaningsih, Herlina. 2009. Thesis: Perbandingan Karekteristik Dinding dengan Berbagai Macam Ukuran Berdasarkan Pedoman-pedoman yang ada Di lapangan Untuk Rumah Sederhana Tahan Gempa. Jurusan Teknik Sipil dan Lingkungan, Fakultas Teknik, Universitas Gadjah Mada, Yogyakarta.

Skariah Blessen Thomas. $A$ comprehensive review on the applications of waste tire rubberin cement concrete. Elsevier (2015): 13241332.

Xue, Gang. Effect of Modified Rubber Particles Mixing Amount on Properties of Cement Mortar. Hindawi (2017) : 1-6.

Yazdi, M, A, J Yang, and Yihui, H. Su. "A review on Applications of Waste Tire in Concrete" .World Academy of Science, Engineering and Technology 9 (2015) : 1656-1661.

$\mathrm{Yu}$, Yong and Hund $\mathrm{Zu}$. Influence of Rubber Size on Properties of Crumb Rubber Mortars. Material 9 (2016): 1-12. 